\title{
THE RELATIONSHIP BETWEEN CONSUMER DOUBT AND VALUE FOR MONEY ON PURCHASE INTENTION
}

\author{
Janice Ardelia Hareka, Alexander Wahyudi \\ Universitas Ciputra, UC Town, Citraland \\ Surabaya 60219, Indonesia
}

\begin{abstract}
This research is done to find out the relationship between consumer doubt and value for money on purchase intention. This research uses quantitative method by collecting data through questionnaires of 30 respondents, sample is done by purposive random sampling method. In this research, analysis of relationship was done between consumer doubt, and value for money on purchase intention to find out which variables affects purchase intention. What distinguishes this research from other researches is that there is a new product that has been owned yet by the more well-known brand of smartphones, namely the existence of the back screen that is used to take self-photographs by using the rear camera. Hypothesis is done to produces calculation statistics that the factor of purchase intention, that is consumer doubt affecting negatively on purchase intention, and value for money affecting positively on purchase intention.
\end{abstract}

Keywords: consumer doubt, value for money, purchase intention

\section{INTRODUCTION}

In the current digital era, almost all Indonesians use smartphones to facilitate communication. With a smartphone, each individual can easily access the internet, communicate, use a camera, music player, and even play games (Abror, 2018). Smartphone users in Indonesia in 2016 to 2019 have always increased to 92 million, and it is estimated that Indonesia will become an active user country as the fourth largest smartphone in the world after China, India, and America (Indah, 2015). So, this can be an opportunity for smartphone companies to sell their products.

\footnotetext{
*Corresponding Author.

e-mail: awahyudi@ciputra.ac.id
} 
The intense competition in fighting over a market that is so competitive in the telecommunications industry in the smartphone category causes consumers to be confronted by various types and different brands of smartphones. With so many brands that can be chosen by consumers according to their needs, consumers become doubtful about the many choices of smartphones to be purchased.

In this study, the authors focus the research on the Vivo brand. Vivo is an electronics company from China which was founded in 2009, which is a subsidiary of BBK Electronics. Vivo became known in Indonesia in 2012 after releasing the X1 series which was named the first smartphone with Hi-Fi (HighFidelity) audio chipset, and the slimmest body at the time (Ardhi, 2016). With the success of the X1 series products, Vivo is developing technological innovations, ranging from audio chipsets, $2 \mathrm{~K}$ screens, thinnest smartphone sizes, $24 \mathrm{MP}$ front camera, dual front camera, dual SD, under-display fingerprint, screen ratio, Jovi Artificial Intelligence, to two-screen smartphones. In this study, the authors focus their research on Vivo Nex Dual Display products that have a front screen and a rear screen for consumers who want to take selfies using the back camera. The price of this product around $\mathrm{Rp} 10,500,000.00$, which can be said to be quite high when compared to the prices of other smartphones that have already been trusted by consumers. Consumers will tend to doubt the product, whether the money consumers spend will be worth Vivo Nex Dual Display products or not. That is because consumers are sensitive to prices, so consumers pay more attention to prices when making purchases (Roby, 2016).

Innovations developed may be acceptable to consumers or not, so that the Vivo Nex Dual Display has pros and cons through consumer reviews that can influence consumer buying interest. Some of them rate the product positively, and some of them rate negatively. This happens because basically, consumers form doubts about something new (Hawass, 2013) so that these reviews can affect consumer buying interest.

From this background, where the intense competition in the telecommunications industry, especially in the field of smartphones, has caused many choices of products that cannot be separated from each other as challenges in the form of consumer doubt and value for money to attract consumer buying interest. Therefore, the researcher raises the title Relationship of consumer doubt and 
value for money on purchase intention. This title can be correlated to the seven spirits of entrepreneurs, namely calculated risk taking, where the company Vivo must have thought about the risk by setting prices that are almost the same as other smartphones. In the perspective of consumers, they are faced with new products that are still not owned by other well-known smartphones, so potential consumers are willing to take risks when buying this product.

\section{LITERATURE REVIEW}

According to Engel, Blackwell, and Miniard (1995), consumer behavior is a direct action taken by consumers in obtaining and consuming products and or services, including the decision-making process that precedes and follows these actions (Tambunan, 2009). So, it can be concluded that consumer behavior is a study of how individuals, groups, and organizations go through the process of selecting, securing, using, and disposing of products or services to satisfy their needs (Tambunan,2009).

Consumer Doubt is a sense of doubt that arises when faced with a product that can affect a customer's purchase intention. Customers do not feel confident in high-quality products and high innovation, because they think whether the product gives something they want or not. So that it raises doubts about new products or high-quality products (Afzali \& Ahmed, 2016). The indicators of consumer doubt according to Bauer, Rogers, Tornatzky, and Klein in (Sääksjärvi \& Morel, 2010) used in this study are as follows:

- Function doubt

Regarding whether the product can be used, can function properly, and is easily used by consumers.

- Quality doubts

Related to whether the product is of high quality, durable and commensurate with the price paid.

Value for money is the price paid by customers for a product or service based on the value of the product or service for them (Afzali \& Ahmed, 2016). Indicators of value for money according to (Afzali \& Ahmed, 2016) used in this study are as follows: 
- Value match

Related to the tendency of consumers to receive the value and benefits according to the expected value.

- Purchasing power

Related to the tendency of consumers to buy new products according to their purchasing power and the value of money of similar products in the market. Purchase Intention is a decision based on the motivation to buy certain products (Widyanto \& Rachmad Saleh, 2018). Indicators of purchase intention according to Schiffman and Kanuk in (Sääksjärvi \& Morel, 2010) used in this study are as follows:

- Considerations for buying

Related choices faced by consumers about various types of products being marketed.

- Interest in trying

Related to where consumers are willing to try a new product in the market to calculate the advantages and risks of the product.

- Desire to know the product

Related to the desire of consumers to know new products in more detail and depth

- The desire to buy products

Related to consumers' willingness to obtain new products by buying the products offered.

Calculated risk-taking is a brave attitude in making decisions and can predict and calculate risks in decision making (Al Mushowwiru \& Fitria, 2019).

The research conducted by (Afzali \& Ahmed, 2016) aimed to develop a scale to find relationships between consumer doubt, skepticism, familiarity, information search, value for money, and aesthetic design with customer purchase intentions. The results showed that aesthetic design and information retrieval of a product has a significant positive relationship with customer purchase intentions.

Research conducted by (Sugiarto\&Subagio,2014) aimed to analyze the effect of products, service quality, price, and store atmosphere on buying an interest in the Kahyangan Dream of Art Resto Surabaya. This research proves 
that there is a significant influence of product, service quality, price, and store atmosphere on consumer buying interest in Dream of Kahyangan Art Resto Surabaya.

Research conducted by (Bruno,2019) aimed to determine the effect to trust, convenience, and price on consumer buying an interest in online stores. The results of this study indicate that trust, price, and convenience have a positive effect on buying interest variables.

Research conducted by (Kakkos, 2015) aimed to identify the drivers of consumer intention to buy private label brands (stores). The results of this study indicate that the intention to buy a private label was found to be influenced by risk perception, value for money, social value, and brand awareness.

Research conducted by (Jethro, 2019) aimed to examine the effect of consumer doubt, skepticism, intimacy, value for money, information seeking, and aesthetic design on the intention to purchase low-tech innovation from local products. The results of this study indicate that consumer doubt and skepticism have a significant negative effect on buying interest.

Research conducted by (Kusnandri, Mansur, \& Hufron, 2018) aimed to find out and analyze the effects of direct marketing, sales promotion, and price perception simultaneously and partially on consumer buying interest of Indosat Ooredoo's internet data packages. The results of this study indicate that marketing, sales promotions, and price perceptions have a positive and significant effect on consumer buying interest in Indosat Ooredoo internet data packages.

\subsection{Relationship Between Consumer Doubt Against Purchase Intention}

It is estimated that consumer doubt is one of the factors that can influence customer buying intentions which plays an important role in customer responses to new products or innovations. Consumer doubt is related to personal questions that consumers usually ask themselves: "is this product right for me?" This is defined if the product meets their expectations (Sääksjärvi\&Morel,2010). For new products or innovative products that have not been available before on the market, customers are usually not sure whether the product will give them something. 
In a previous study conducted, (Jethro, 2019) stated that consumer doubt had a negative effect on buying interest. Based on the review of these literatures, the first hypothesis proposed in this study is:

H1: Consumer Doubt has a negative effect on purchase intention

\subsection{Relationship Between Value for Money Against Purchase Intention}

In marketing, one of the most important and challenging things for companies is product pricing. Marketers usually try to set prices for products based on the value the product has to customers but in real situations companies determine prices based on the cost of producing the products (Afzali \& Ahmed, 2016). The value of money is defined as the price or money customers will pay for a product or service based on how much the product or service is worth to them (Afzali \& Ahmed, 2016).

In a study conducted by (Eka, 2016), the value of money has a significant positive effect on buying interest variables. Based on the review of literatures, the second hypothesis proposed in this study is:

H2: Value for money has a positive effect on purchase intention

\subsection{Figure}

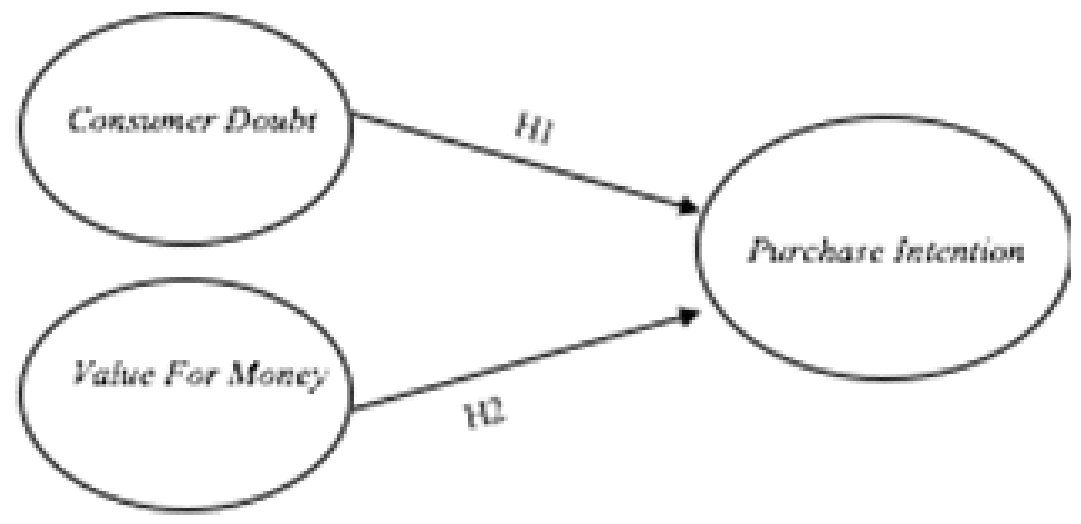

Figure 1 Analysis Model 
Table 1 Loading Factors

\begin{tabular}{|c|c|c|c|}
\hline & $\begin{array}{c}\text { Consumer } \\
\text { Doubt }\end{array}$ & $\begin{array}{c}\text { Value } \\
\text { for Money }\end{array}$ & $\begin{array}{c}\text { Purchase } \\
\text { Intention }\end{array}$ \\
\hline X1.1 & 0,905 & & \\
\hline X1.2 & 0,904 & & \\
\hline X1.3 & 0,514 & & \\
\hline X1.4 & 0,840 & & \\
\hline X1.5 & 0,835 & & \\
\hline X2.1 & & 0,879 & \\
\hline X2.2 & & 0,861 & \\
\hline X2.3 & & 0,759 & \\
\hline X2.4 & & 0,807 & \\
\hline Y1.1 & & & 0,780 \\
\hline Y1.2 & & & 0,868 \\
\hline Y1.3 & & & 0,824 \\
\hline Y1.4 & & & 0,882 \\
\hline
\end{tabular}

According to Ghozali and Latan, for explanatory research the value of loading factors that can still be tolerated is 0.6 to 0.7 . However, for the initial stage of developing the measurement scale, a loading factor value of 0.5 to 0.6 is still considered sufficient (Subagiyo, 2017). The table shows all indicators are above 0.5 so that the indicators can be concluded as valid.

Table 2 AVE (Average Variance Extracted)

\begin{tabular}{|l|l|}
\hline \multicolumn{2}{|c|}{ AVE } \\
\hline Consumer Doubt & 0,661 \\
\hline Value For Money & 0,686 \\
\hline Purchase Intention & 0,705 \\
\hline
\end{tabular}

It can be seen that the purchase intention has the highest AVE, which is 0.705 , the value for money has the AVE of 0.686 , and consumer doubt has the 
lowest AVE, which is 0.661 . Consider the statement by (Yogianto, 2008) that the variable is said to be valid if AVE (Average Variance Extracted) is greater than 0.5 . In the table it can be seen that all variables are declared valid.

Table 3 Cross-Loading

\begin{tabular}{|c|c|c|c|}
\hline & $\begin{array}{c}\text { Consumer } \\
\text { Doubt }\end{array}$ & $\begin{array}{c}\text { Value for } \\
\text { Money }\end{array}$ & $\begin{array}{c}\text { Purchase } \\
\text { Intention }\end{array}$ \\
\hline $\mathrm{X} 1.1$ & $\mathbf{0 , 9 0 5}$ & 0,046 & $-0,170$ \\
\hline $\mathrm{X} 1.2$ & $\mathbf{0 , 9 0 4}$ & $-0,021$ & $-0,217$ \\
\hline $\mathrm{X} 1.3$ & $\mathbf{0 , 5 1 4}$ & 0,260 & 0,120 \\
\hline $\mathrm{X} 1.4$ & $\mathbf{0 , 8 4 0}$ & 0,127 & $-0,121$ \\
\hline $\mathrm{X} 1.5$ & $\mathbf{0 , 8 3 5}$ & 0,151 & $-0,162$ \\
\hline $\mathrm{X} 2.1$ & $-0,074$ & $\mathbf{0 , 8 7 9}$ & 0,712 \\
\hline $\mathrm{X} 2.2$ & 0,022 & $\mathbf{0 , 8 6 1}$ & 0,698 \\
\hline $\mathrm{X} 2.3$ & 0,094 & $\mathbf{0 , 7 5 9}$ & 0,562 \\
\hline $\mathrm{X} 2.4$ & 0,052 & $\mathbf{0 , 8 0 7}$ & 0,660 \\
\hline $\mathrm{Y} 1.1$ & $-0,277$ & 0,612 & $\mathbf{0 , 7 8 0}$ \\
\hline $\mathrm{Y} 1.2$ & $-0,408$ & 0,697 & $\mathbf{0 , 8 6 8}$ \\
\hline $\mathrm{Y} 1.3$ & $-0,026$ & 0,681 & $\mathbf{0 , 8 2 4}$ \\
\hline $\mathrm{Y} 1.4$ & $-0,092$ & 0,688 & $\mathbf{0 , 8 8 2}$ \\
\hline
\end{tabular}

Indicators are said to meet the discriminant validity if the value of cross loading of a variable is the largest compared to other variables (Katopo, 2015). In table it can be seen that the cross-loading value of each variable is the greatest when compared to other variables, so it can be concluded that the data is valid.

Table 4 Reliability Test

\begin{tabular}{|l|c|c|}
\hline \multicolumn{1}{|c|}{ Indikator } & $\begin{array}{c}\text { Cronbachs } \\
\text { Alpha }\end{array}$ & $\begin{array}{c}\text { Composite } \\
\text { Reliability }\end{array}$ \\
\hline Consumer Doubt & 0,907 & 0,904 \\
\hline Value for Money & 0,846 & 0,897 \\
\hline Purchase Intention & 0,860 & 0,905 \\
\hline
\end{tabular}

It can be seen that consumer doubt has the highest Cronbach's alpha of 0.907, purchase intention has a Cronbach's alpha of 0.860 , and value for money 
has the lowest Cronbach's alpha of 0.846 . While purchase intention has the highest composite reliability of 0.905 , consumer doubt has a composite reliability of 0.904 , and value for money has the lowest composite reliability of 0.897 . From these data, all values of all variables are more than 0.7 , so it can be concluded that the data is reliable.

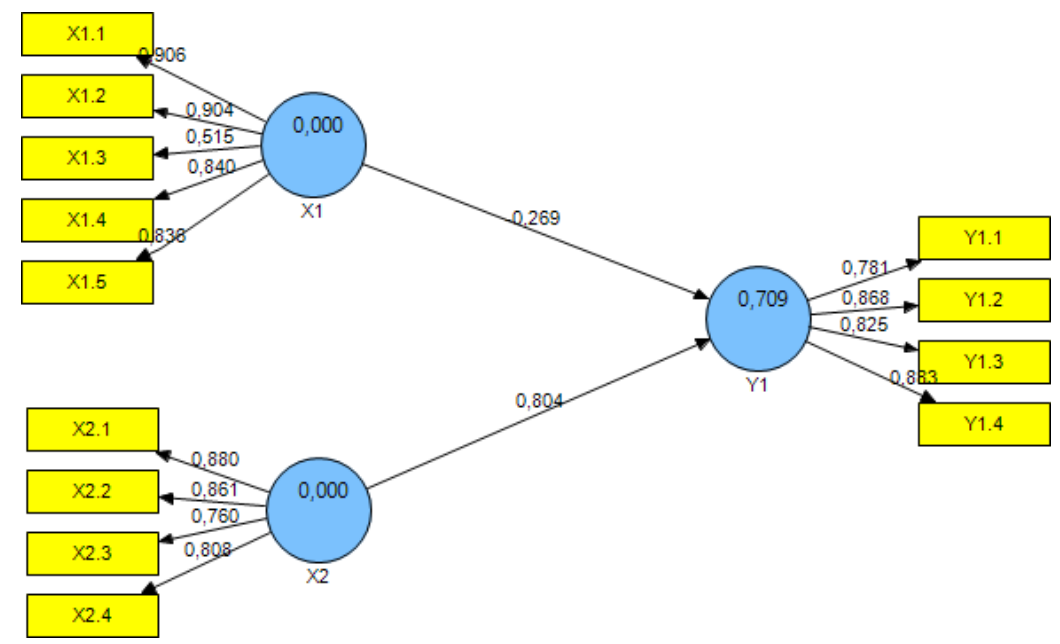

Figure 3 Model Analysis PLS Algorithm

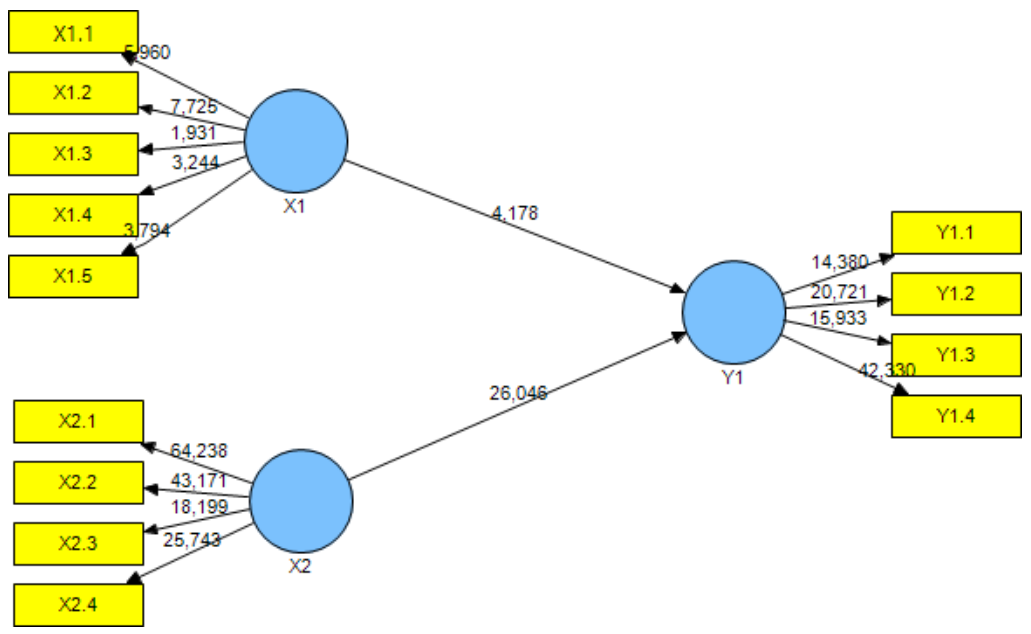

Figure 4 Model Analysis PLS Bootstrapping 
Table 5 T-statistics

\begin{tabular}{|c|c|}
\hline \multicolumn{2}{|c|}{ T-Statistics } \\
\hline $\mathrm{X} 1$ - > Y1 & 3,287 \\
\hline $\mathrm{X} 2$ - > Y1 & 30,257 \\
\hline
\end{tabular}

It can be seen that the t-statistic of consumer doubt towards purchase intention is 3,287, and the t-statistic of value for money against purchase intention is 30,257 . In this data, the relationship between value for money to purchase intention is greater than the relationship between consumer doubt against purchase intention.

\subsection{Equation}

The average value of each variable is determined by category with the interval of each class for each Likert scale. The interval formula used is as follows (Widodo, 2016):

$$
\text { Interval Kelas }=\frac{\text { Nilai tertinggi }- \text { Nilai terendah }}{\text { Jumlah Kelas }}=\frac{5-1}{5}=0,8
$$

Based on the interval formula used, the respondent's answer criteria are as follows:

\begin{tabular}{|c|l|}
\hline \multicolumn{1}{|c|}{ Interval } & \multicolumn{1}{c|}{ Category } \\
\hline $4.20<$ average $\leq 5.00$ & Strongly Agree \\
\hline $3.40<$ average $\leq 4.20$ & Agree \\
\hline $2.60<$ average $\leq 3.40$ & Neutral \\
\hline $1.80<$ average $\leq 2.60$ & Disagree \\
\hline $1.00<$ average $\leq 1.80$ & Strongly Disagree \\
\hline
\end{tabular}


Janice Ardelia Hareka, Alexander Wahyudi / The Relationship between Consumer Doubt and Value for Money on Purchase Intention

\section{RESEARCH METHODS}

\subsection{Results}

The research used in this research is explanatory research. According to Sugiyono in (Efry,2017) explanatory research is research that explains the variables studied as well as the relationship of one variable with other variables. The population used in this study was Smartphone users within the University of Ciputra. The sampling technique used in this study was purposive random sampling, which prioritized the purpose of the study rather than the nature of the population (Bungin, 2015) with a total sample of 30 respondents. The data is taken using the Roscoe Theory where the number of samples is at least ten times the number of variables (Murti \& Putri, 2018). This research was measured using a Likert scale, where respondents determine the level of their agreement to the questions given by choosing the answers that have been determined (Maryuliana et.al,2016).

\section{DISCUSSION}

\subsection{The Relationship between Consumer Doubt on Purchase Intention}

The results obtained from this study indicate that consumer doubt has a significant negative effect on purchase intention. It is known that the t-value greater than $\mathrm{t}$-table, where the $\mathrm{t}$-value of 3.287 . The $\mathrm{t}$ - count is positive because the statement from the consumer doubt questionnaire is negative. For new products or innovative products that have not existed before in the market, customers are usually not sure whether the product will give them something, so that arises doubt (Sääksjärvi\&Morel,2010). Prospective consumers are hesitant about Vivo Nex Dual Display products because the brand of Vivo itself is less trusted by consumers, so it becomes a consideration for potential consumers to buy Vivo Nex Dual Display products. In addition, through the research conducted, the highest mean of consumer doubt is at indicator X1.2 which states that respondents doubt that the Vivo Nex Dual Display product always functions properly. This happens because the Vivo is known as an easy-to-error smartphone when the smartphone gets hot and the Vivo Nex Dual Display product has a fragile screen. Indicator X1.2 also has a low standard deviation, which is 0.20 
where the answers of each respondent have the same answers, so it can be said that the respondent agrees with the statement of indicator X1.2.

The results of this study support the research conducted by (Jethro,2019) which stated that consumer doubt has a negative effect on buying interest.

\subsection{The Relationship between Value for Money on Purchase Intention}

The results obtained from this study indicate that value for money has a significant positive effect on purchase intention. It is known that the $t$-count greater than $\mathrm{t}$-table, where the $\mathrm{t}$-count is 30.257 . According to Norberg in (Afzali \& Ahmed, 2016), the willingness of customers to pay with the value of the money they get from a product has a relationship with the customer's purchase intention. In this study, the highest mean is at indicator X2.3 which states that the price of the Vivo Nex Dual Display product is in accordance with the purchasing power of prospective consumers, even though the Vivo Nex Dual Display product has a high enough price, which is around $\mathrm{Rp} 10,500,000.00$ and is said to be quite high when compared to other smartphone brands that are more famous. In addition, potential customers state that the price is in accordance with their purchasing power and will be in accordance with the benefits they will feel, because other smartphones that are more famous do not have Vivo's innovation. Indicator X2.3 has a low standard deviation of 0.018 where the answers of each respondent are mostly in common, so it can be said that the respondent agrees with the statement of indicator X2.3. Through this, it can be concluded that respondents have the willingness to buy Vivo Nex Dual Display products, where the higher the willingness of consumers to pay for a product the higher the consumer's interest in buying.

The results of this study support the research conducted by (Susilo \& Semuel, 2015) which stated that the value of money has a significant positive effect on purchase intention.

\section{CONCLUSION}

Based on the description of the discussion in the previous chapter, the following can be concluded: 
Janice Ardelia Hareka, Alexander Wahyudi / The Relationship between Consumer Doubt and Value for Money on Purchase Intention

- Consumer doubt has a significant negative effect on purchase intention

- Value for money has a significant positive effect on purchase intention

\section{REFERENCES}

Abror, F. (2018). Jumlah Pengguna Smartphone di Indonesia. Retrieved January 24, 2018, from Indonesiabaik.id website: http://indonesiabaik.id/infografis/ jumlah-pengguna-smartphone-di- indonesia-18.

Afzali, M., \& Ahmed, E. M. (2016). World Journal of Entrepreneurship, Management and Sustainable Development Article Information/: 11(2), 100-119. Retrievedfrom http://dx.doi.org/10.1\%5Cn108/WJEMSD-1\%5Cn1-2013005\%5Cn.

Al Mushowwiru, A. A. \& Fitria, S. E. (2019). Pengaruh Entrepreneurial Marketing Terhadap Kinerja Umkm Sentra Kulit Garut Sukaregang. Jurnal Ilmu Sosial Politik dan Humaniora, 2(1), 17-29. https://doi.org/10.36624/jisora. v2i1.26.

Ardhi, S. (2016). Vivo, "Si Anak Baru” di Lima Besar Vendor Ponsel Dunia.

Bruno, L. (2019). Pengaruh Kepercayaan, Harga, dan Kemudahan Terhadap Minat

Beli Konsumen pada Toko Online (Studi pada Toko Online OLX.co,id). Journal of Chemical Information and Modeling, 53(9), 1689-1699. https://doi.org/ 10.1017/CBO9781107415324.004.

Bungin, B. (2015). Metodologi Penelitian Sosial \& Ekonomi (1st ed.).

Eka, P. (2016). Dengan Niat Beli Smartphone Merek Samsung Ekonomi dan Bisnis Universitas Udayana, Bali, Indonesia Sektor Industri Teknologi yang Sedang Berkembang Pesat Saat ini adalah Teknologi Ponsel Cerdas (Smartphone). Smartphone Menjadi Konfigurasi Standardian, 5(10), 6762-6794.

Hawass, H. H. (2013). Brand Trust: Implications from Consumer Doubts in the Egyptian Mobile Phone Market. Journal of Islamic Marketing, 4(1), 80100. https://doi.org/10.1108/17590831311306363.

Indah, R. (2015). Indonesia Raksasa Teknologi Digital Asia. Retrieved from Kementerian Komunikasi dan Informatika Republik Indonesia website: https://kominfo.go.id/content/detail/6095/indonesia-raksasa-teknologi-digitalasia/0/sorotan_media.Jethro, J. (2019). Explanatory study of factors affect- 
ing purchase intention of low-technology innovation of local products in Surabaya. 308 (Insyma), 136-139. https://doi.org/10.2991/insyma-19. 2019.35.

Kakkos, N. (2015). Identifying Drivers of Purchase Intention for Private Label Brands. Preliminary Evidence from Greek Consumers. Procedia - Social and Behavioral Sciences, 175, 522-528. https://doi.org/10.1016/j.sbspro. 2015.01.1232.

Katopo, F. (2015). Analisa Pengaruh Individual Factor Terhadap Entrepreneur Motivation Mahasiswa Manajemen Bisnis Universitas Kristen Petra Surabaya. Agora, 3(1), 677-685.

Kusnandri, A., Mansur, M., \& Hufron, M. (2018). Pengaruh Direct Marketing, Sales Promotion dan Persepsi Harga Terhadap Minat Beli Konsumen (StudiKasus pada Pengguna Paket Data Internet Indosat Ooredoo Mahasiswa Fakultas Ekonomi dan Bisnis Universitas Islam Malang), 7(7), 34-45. Retrieved from http://www.riset.unisma.ac.id/index.php/jrm/article/view/ 1182.

Maryuliana et.al. (2016). Sistem Informasi Angket Pengukuran Skala Kebutuhan Materi Pembelajaran Tambahan sebagai Pendukung Pengambilan Keputusan di Sekolah Menengah Atas Menggunakan Skala Likert. Jurnal Transistor Elektro dan Informatika (TRANSISTOR EI), 1(2), 1-12. Retrieved fromhttp:/ /jurnal.unissula.ac.id/index.php/EI/article/view/829.

Murti, A. T. \& Putri, S. A. (2018). Faktor-Faktor yang Mempengaruhi Permintaan Daging Broiler di Kota Malang. Buana Sains, 18(1), 47. https://oi.org/ 10.33366/bs.v18i1.937.

Roby, J. (2016). Analisis Pengaruh Promosi, Harga, dan Atribut Produk Terhadap Perpindahan Merek (Brand Switching) Kartu Seluler di STIE Totalwin Semarang. Retrieved from http://eprints.undip.ac.id/48117/.

Sääksjärvi, M., \& Morel, K. P. n. (2010). The Development of a Scale to Measure Consumer Doubt toward New Products. European Journal of Innovation Management, 13(3), 272-293. https://doi.org/10.1108/14601061011060120. Subagiyo.(2017). Pengaruh Customer Satisfaction Terhadap Customer Loyalty pada Pembeli Tiket Online Pesawat di Surabaya. 6(2),104-130.

Sugiarto, B. U., \& Subagio, H. (2014). Analisa Pengaruh Produk, Kualitas Pelayanan, Harga, dan Store Atmosphere Terhadap Minat Beli di Dream of 
Khayangan Art Resto Surabaya. Jurnal Manajemen Pemasaran Petra, 2(1), 1-14. Retrieved from http://publication.petra.ac.id/index.php/manajemenpemasaran/article/view/2318.

Susilo, I. \& Semuel, H. (2015). ANALISA PENGARUH EMOTIONAL MARKETING TERHADAP PURCHASE INTENTION MELALUI BRAND AWARENESS PADA PRODUK. 9(1), 23-34.

https://doi.org/10.9744/pemasaran.9.1.23-34.

Tambunan, D. B. (2009). Atribut yang Menjadi Pertimbangan Konsumen dalam Membeli Produk Perumahan. Jurnal Manajemen Bisnis, 2(2), 141-153.

Widodo. (2016). Draft Buku Ajar Kantor Depan. Retrieved from http:// repository.umy.ac.id/bitstream/handle/123456789/4556/DraftStatRev2016. pdf? sequence $=2 \&$ i sAllowed $=y$.

Widyanto, H. A. \& Rachmad Saleh, T. A. (2018). The Influence of Customers' Perception And Attitudes Toward Customer Purchase Intention At Gramedia Lembuswana, Samarinda. Firm Journal of Management Studies, 3(1), 84. https://doi.org/10.33021/firm.v3i1.387.

Yogianto. (2008). Konsep Aplikasi PLS untuk Penelitian Empiris. 
Review of Management and Entrepreneurship

Volume 04, Number 01, April 2020 